\title{
Construction of Legitimacy in Neo-Confucianism
}

\author{
Yibo ZHAI
}

\author{
The University of Hong Kong, Hong Kong, China \\ *zhaiyibo992@outlook.com
}

\begin{abstract}
As China's modernization continues to accelerate, the traditional sources of legitimacy for governance are at risk. Mainland Neo-Confucian scholars have sought to provide a source of legitimacy using traditional Confucian theories. As a part of the most influential ruling philosophy in ancient China, Confucianism has had been crucial to Chinese civilization for thousands of years. It is of great practical importance to test whether the return to Confucianism advocated by Neo-Confucian scholars can resolve the dilemma of legitimacy in China.
\end{abstract}

Keywords: Legitimacy, Neo-Confucianism

\section{INTRODUCTION}

\subsection{Statement of the Importance}

Legitimacy is a central concept in the history of political philosophy and is a crucial factor in a practical sense for regime stability [1]. It has not attracted the attention of either Western or Chinese scholars and politicians. Wang Qishan discussed the concept of public legitimacy of the Chinese Communist Party (CCP) [2]. Chinese scholars also have included considerations of legitimacy in academic discussions, such as NeoConfucian scholars in the mainland. Unlike the NeoConfucianism studies in Taiwan and Hong Kong, which focus on the school of Mind Confucianism developed in Song and Ming dynasties, contemporary mainland NeoConfucianism studies tend to focus on the political aspects of Confucianism. They seek to integrate Confucianism into Chinese politics and society. Using traditional Confucianism, they have developed political theories, and governance models to construct legitimacy with Confucian characteristics.

\subsection{Methodology}

This thesis uses textual analysis to investigate the construction of legitimacy by mainland Neo-Confucian scholars in detail. Furthermore, the modernization theory is used to indicate whether the construction theory of mainland Neo-Confucianists can be successful and whether their theory can solve the shortcomings of legitimacy problem.

\subsection{Summary of the Thesis}

This paper describes the rise of Neo-Confucianism to enable its perspective on the construction of legitimacy. Then, it analyzes the ideas of legitimacy in NeoConfucianism in detail. Finally, it presents an overall evaluation.

\section{LITERATURE REVIEW}

Ideology can provide a basis for legitimacy [3], which is used by Neo-Confucianism to construct legitimacy for China. For example, Kang Xiaoguang proposed establishing Confucian hegemony to maintain the legitimacy of benevolent governance [4]p163. Jiang Qing presented a political model based on the traditional Confucian idea of the three generations of sage kings (referring to the Xia, Shang, and Zhou dynasties). He considered his political Confucianism an approach to establishing a triple legitimacy [5] that can truly outcompete the Western liberal democratic system. Gan Yang identified three traditions of Confucianism, Maoism, and Deng Xiaoping's theory in contemporary China, which, in their combination, support a powerful civilization. Numerous mainland Neo-Confucianists believe that a Confucian civilization can be reestablished based on CCP [6]. This thesis investigates such attempts to construct legitimacy and analyzes whether their constructions are successful. 


\section{OVERVIEW}

\subsection{Rise of Contemporary Neo-Confucianism in China}

Since China's accession to the World Trade Organization, its GDP has been growing at a high annual rate, and it has caught up with many developed countries. In 2008, the global financial tsunami occurred. The Chinese economy maintained stable growth with its strong fiscal and regulatory capabilities. The growth of such national power stimulated the ambitions of these Neo-Confucian scholars in the mainland, who were not satisfied with the existing international order dominated by the United States. At the same time, they highlighted the problem of modernization [7] and hold that returning to classical Chinese political thought would be a better approach to face modernization [8].

\subsection{Legitimacy Crisis}

Some scholars believe that authoritarian regimes cannot develop the procedural legitimacy that is possible in democratic regimes. The government's performance is the only source of legitimacy in contemporary China [9]. Therefore, the ongoing economic development is the key to the continuance of the CCP's one-party system. However, the economy alone cannot completely explain the legitimation of the CCP [1]p2. Besides, since the market reform in 1970, the country has experienced the contradiction: on the one hand, the country must rely on capitalist economic policies to promote economic growth; on the other hand, it is bound by the dogmas of communism and socialism. This contradiction between dogma and real-life inevitably leads to a decline in faith in communism [1]p. 3. As Daniel Bell wrote, Marxism can no longer provide the current CCP with the ideological legitimacy of ruling because even the "communist government won't be confined by Marxist theory" [10].

Mainland Neo-Confucian scholars observed the shortcomings of legitimacy in China. Therefore, maintaining legitimacy by ideology became the major measure for mainland Neo-Confucian scholars. For example, Jiang Qing wanted to replace Marxism with Confucianism, and Gan Yang replaced Marxism with Mao and Deng's theory [6]p6. While acknowledging that the CCP is the only legal ruling party in China, they keep using Confucian concepts to explain contemporary China's problems so as to ensure the success of the ideological transformation.

\section{CONSTRUCTION OF LEGITIMACY}

Many Western scholars consider the legitimacy of the Chinese government by using Western approaches, such as normative theory [1]p56, and regard democracy and human rights as the foundation. Inevitably, they conclude that the CCP lacks legitimacy. However, NeoConfucianism considers that in the Chinese context, the legitimacy of China's politics is determined by the views of the Chinese people. Based on this, they use Confucian theories to reconstruct the theory of legitimacy based on Chinese cultural background.

\subsection{Jiang Qing: the Politics of Kingly Way}

Jiang Qing believes that Marxism can hardly become the source of legitimacy as a foreign ideology. On contrary, Confucianism, as a religion, can do so because it can: 1) solve the problems of legitimacy in the political order, thus establishing a value foundation for political power that makes it superior to sacredness; 2) solve the problems of behavioral norms in society, and establish the daily routine of Chinese people with the system of rites and music; 3) solve the problems of beliefs, and stabilize people's spiritual life using the Heaven, the gods, the laws of nature, and the disposition and heavenly principles [11]. Today, the above three functions of Confucianism still stand, and the reconstruction of Confucianism can solve the current problems of legitimacy in China. On this basis, "Political Confucianism" is proposed.

Kingly Way [12] is the core concept of political Confucianism. According to Jiang, "(benevolent) governance by the kingly way, as the name suggests, can be referred to as politics run on the basis of the sage state rulers in Confucian terms" [5]p202. Legitimacy in governance by the kingly way can only be achieved by satisfying the following three components, namely the legitimacy of "Heaven", "Earth" and "Human" [12]. The legitimacy of Heaven refers to that which transcends sacredness. Heaven carries four connotations on its own, i.e., Heaven of rule, Heaven of will, Heaven of nature, and Heaven of righteousness. Jiang also interprets this sacredness-transcending legitimacy as "morality" or "substantial morality". The legitimacy of Earth refers to the legitimacy of history and culture, i.e., history and culture emerged in a specific geographical space, and every nation has a political order that goes by its own cultural heritage and orthodoxy. In China, Confucian tradition and orthodoxy must be followed. The legitimacy of Human refers to the legitimacy of people's will because people's recognition directly determines whether they voluntarily submit to political power or political authority[5]pp202-211. Based on the harmonious coexistence of Heaven, Earth, and Human, the tripartite legitimacies of public opinions, sacredness, and culture coexist to counterbalance the kingly way as a core.

According to the "tripartite legitimacy", Jiang Qing proposed the contemporary design of the "tri-cameral legislature" [11] political system, whereby the 
parliament implements a three-chamber system, with each chamber representing one aspect of legitimacy.

The House of Profound Confucians represents the legitimacy of sacredness transcendence, standing as the house of representatives for Confucian values. It consists of recommended and appointed Confucian scholars, each of whom must have developed a thorough understanding of Confucian classics, such as the Four Books and Five Classics. The House of Plebeians represents the legitimacy of popular opinions, and it is formed through general elections and elections among functional constituencies. The House of National Continuity represents the legitimacy of history and culture, playing roles equivalent to those held by the House of Nobility in ancient Western countries, which makes it eligible inheritors of the aristocratic traditions. It includes the descendants of past sages, descendants of past monarchs, descendants of historically and culturally distinguished, descendants of the nation's loyal servants, professors in national history in universities, the nation's retired senior administrative officials, judicial officials, diplomatic officials, social elites, and followers of the Taoist and Buddhist circles, as well as Muslims, Lamaists, and Christians.

Each of the three houses is granted with substantive parliamentary powers, so after the emergence of the three parliamentary houses, proposed bills, depending on their gravity, must pass the scrutiny of all three houses for highly-crucial bills, or two houses for moderately-crucial bills, before they have a chance of being promulgated.

\subsection{Kang Xiaoguang: Politics of Benevolent Governance}

Kang Xiaoguang criticizes democratization in two aspects: validity and legitimacy. Kang claims that democratization is not necessarily able to remove or relieve political corruption, economic risk, social injustice, and other problems faced by China, and "what we have achieved may be lost, such as economic boom, political stability, national unity, and national solidarity" [4]p143. Kang replaces "democracy" with the theory of "benevolent governance" and holds that this theory is "the theory of the legitimacy of China's authoritarian government" [13].

There are three prerequisites to establish the legitimacy of benevolent governance:

1) It is necessary to establish the hegemony of Confucian culture and exercise the dictatorship of the Confucian community. This is because the way of heaven is above the will of the people, and only the Confucian community can realize the way of heaven.

2) If benevolent governance is the best political system, then political parties that do not believe in
Confucian concepts are not eligible to be in power. Therefore, Confucianism opposes the multiparty system.

3) Confucianism objects to "universal suffrage". Although Confucianism acknowledges the principle of equality, equality is just a possibility that, Confucianism argues that people are unequal, and that there is a distinction between the virtuous and the not virtuous. Confucianism claims that men of great virtue should rule men of small virtue, and more able men should rule less able men. In other words, only the able are eligible to rule. Mencius said that "only the benevolent are fit for the high position". Confucians are virtuous and benevolent people, so the ruler can only be elected by the Confucian community, without the need to hold a referendum. Confucianism asserts that although people outside the Confucian community do not have the right to rule, they are entitled to good governance. In other words, the ruled have the right to require the ruler to exercise benevolent governance. This is an inalienable right of the ruled.

To sum up, the ultimate goal of Kang Xiaoguang is to establish a "Confucian state", and the course of founding a Confucian state is "Confucianization". The strategy is to replace the existing ideology with the doctrines of Confucius and Mencius: retain the party schools with the Four Books and Five Classics as textbooks and incorporate Confucianism into the examinations for civil servants [4]p164. In this way, an institutionalized and monopolistic connection between Confucian learning and politics can be established. Benevolent governance is realized when the ruling party becomes the Confucian community.

\section{REFLECTION}

\subsection{On the Issue of Institutionalization of Confucianism}

The so-called institutionalization of Confucianism refers to a series of institutional designs made by the ruler after the Confucian school was established as the national ideology so as to ensure the sole dominancy of Confucianism. In the Han Dynasty, the scholar-official of the Five Classics was set so that the literature of Confucianism was canonized, and the Confucian morality promoted. By the exercise of power, the commemoration of Confucius was promoted from spontaneous activities of Confucius' disciples to a national ceremony, and the Confucius Temple from ancestral temple to the site of the imperial sacrificial ceremony. The rulers worshiped the Confucian school to reinforce the legitimacy of their rule; in the meantime, Confucian scholars further preached Confucianism and raised the status of Confucius through the ruling power. A typical event of the institutionalization of Confucianism is the introduction of the imperial examination system in the Sui Dynasty. It is the system that elects officials by examining candidates' 
understanding of the knowledge and thoughts of Confucianism. In the following 1,300 years, Confucianism served as a stepping-stone for generations of Confucian scholars to stand out and successfully start their official careers.

The imperial examination system, as the junction of truth and power, is of great significance to the stability of the institutionalized Confucian system. However, it was abolished in the Qing Dynasty, of which the main reasons were: 1) Social cohesion required an appropriate kernel model to convey the message to a larger audience. As a result, the examination focused more on a few of the Confucian classics, such as the Four Books, leading to partial expression of and even deviation from the original Confucian thoughts. For instance, in the late Qing Dynasty, people insistently overemphasized the format while ignoring the content of such examinations, even paying more attention to the form of written characters than recognition of the Confucian philosophy. 2) For control or even exclusion of various competing interpretations of the social order such as that clearly advertised under "Confucianism as the sole dominant ideology", the mainstream thinking became rigid due to lack of inner dynamics, and the society became listless. 3) Virtues could be tested through the system, by which a man could be advanced in rank and made a higher official. In such a context, corruption was inevitable. There was even official trade of government posts. Money wore down the sanctity of the institutional design that served as the foundation of the rule, from which the legitimacy of the rule as a whole was naturally demolished, so were the shared values based on Confucianism.

Therefore, the institutionalization of the morality system is fragile. To ensure that the non-Confucian thought wouldn't become rigid and the function departments wouldn't corrupt, the theories of NeoConfucianism were far from adequate.

\subsection{Criticism of the Confucian Elitism}

The establishment of Confucianism as state religion advocated by Jiang Qing and Confucian hegemony held by Kang Xiaoguang were both the conception of Confucian elitism. Both Jiang and Kang believed that: only elite Confucian scholars discern the proper governance of a state. On the one hand, those who didn't embrace Confucianism certainly would be suppressed. For instance, Kang agreed that sovereignty belonged to all the people, but insisted on the administrative power only for the community of Confucian scholars. This rendered popular sovereignty unfeasible. Jiang's parliamentary system was declared tricameral but in fact bicameral, because the main body of the House of Profound Confucians and the House of National Continuity (though formed in different ways) was the same - the Confucianists. It was so designed tricameral just to suppress those who didn't believe in Confucianism with the so-called morality, history, and culture. The two chambers were naturally homogeneous. If they joined hands in the name of Confucianism, the voice of the House of Plebeians of the common people would be covered up completely.

On the other hand, many facts show that people could not tell whether a person is a real Confucian master or not. For example, in the War of Resistance against Japan, Wang Yitang, one of the "Big Three" traitors in the false Government Affairs Committee of North China, was a "master of studies of Chinese ancient civilization". As he helped the Japanese kill and maim people in North China for "public security and order", he also started "schools of Chinese classics" and gave training courses for young children to enslave people by studies of Chinese ancient civilization. Zheng Jiadong, former director of the research office for the history of the Chinese philosophy of the Institute of Philosophy of the Chinese Academy of Social Sciences, is up to the title of "a master Confucian scholar in the modern age". But in 2005, he was arrested for suspected smuggling of six women. The question here is, how to tell the men of virtue from those of vile character in Confucian scholars. If people are not able to distinguish true Confucian scholars from the false ones beforehand, how could people let the elites among them rule legitimately?

\subsection{The Value of Equality}

Equality is an important modern value. Yu Yingshi mentioned in his famous book Contemporary Significance of Chinese culture from the Perspective of Value System that "the Confucian school emphasizes both 'benevolence dependent on oneself', i.e. individual consciousness of value, at the same time, they stress human relations and social order" [15] As for NeoConfucianism in Hong Kong and Taiwan, it is not that hard to agree with equality between men and women. Their theory is based on Confucianism of Mind rather than Confucianism of politics. Whether or not "the three cardinal guides and the five constant virtues" could be established today isn't an imminent question for them. However, Neo-Confucianism in mainland China cannot avoid this question. The mainstream attitude taken by them towards equality between men and women is that "the three cardinal guides and the five constant virtues" have some reasons. For example, Qi Yihu of NeoConfucianism once posted on Weibo that, women today would rather work their life away for a strange man (boss) than help their husbands at home, which was quite denounced. The issue of legitimacy is in its nature the issue of the relationship between people and state or, in popular terms, "why should I follow your rules?" Women often ask "why" when they are aware of the stereotypes held by the majority of society (mostly men) about their dressing and behavior. Such a theory totally against 
equality between men and women will to what extent be accepted by women in China?

\subsection{Summary}

In a word, advocating morality is good, but the emphasis should be on the ways to promote morality. Promoting morality through wrong ways will to the contrary encourage hypocrisy and autocracy. In the end, people will not only abandon such politics but also disgust morality as its companion.

\section{CONCLUSION}

Starting from the sentiment of doing good to society of political Confucianism, today's Neo-Confucianism in mainland China calls for the reconstruction of Confucianism. Yet their reconstruction is not a success. On the one hand, political Confucianism failed to handle the complexity of tradition and modernity and simply reduced modern thinking when striving to restore traditional morality and politics. Eventually, they put themselves on a narrow path leading all their conceived theory to a Utopian proclamation. On the other hand, the theory of Neo-Confucianism held high moral ideals while taking politics as the tool for realizing morality. They lay one-sided emphasis on the divinity of political power while ignoring the unification of politics and Confucianism, causing tragic consequences.

Confucianism as political philosophy might have become outdated because it can no longer meet citizens' demand for political legitimacy in contemporary society. However, the Confucian moral philosophy is not entirely obsolete. Such Confucian values as benevolence, justice, courtesy, wisdom, and faith, the doctrine of mean and harmony are still of universality that transcends time and space. Meanwhile, the Confucian doctrines require Confucianists to keep an open mind. The Analects of Confucius opens with "is it not pleasant to learn with a constant perseverance and application?" [15]. As Confucianism emphasizes learning the most, NeoConfucianism should also avoid confining itself to the old theory.

\section{REFERENCES}

[1] Jinghan Zeng, The Chinese Communist Party's Capacity to Rule: Ideology, Legitimacy and Party Cohesion, Palgrave Macmillan, 2016, pp. 2-4, pp. 56.

[2] Jian Chen, Wang Qishan Meets with Foreign Representatives Attending the "2015 Dialogue between the Communist Party of China and the World", Xinhua, 2015. www.xinhuanet.com/politics/201509/09/c_1116513917.htm
[3] Samuel P. Huntington, Political Order in Changing Societies, Yale University Press, 1968, pp. 8.

[4] Xiaoguang Kang, Prosecute, Hong Kong: Ming Pao Education Publications Limited, 2005, pp. 143, pp. 163-164.

[5] Qing Jiang, Political Confucianism: the contemporary transformation of Confucianism, Beijing: SDX Joint Publishing Company, 2003, pp. 202-211.

[6] Yang Gan, Integrating Three Traditions, Beijing: SDX Joint Publishing Company, 2007.

[7] Lu, Ye, et al, "Mass Media, New Technology, and Ideology: An Analysis of Political Trends in China", Global Media and China, vol. 1, no. 1-2, 2016, pp. 70-101. DOI: $10.1177 / 2059436416648799$

[8] Edmund S. K. Fung, The Intellectual Foundations of Chinese Modernity: Cultural and Political Thought in the Republican Era, Cambridge University Press, 2016, pp. 93.

[9] Dingxin Zhao, "The Mandate of Heaven and Performance Legitimation in Historical and Contemporary China", American Behavioral Scientist, vol. 53, no. 3, 2009, pp. 416-433. DOI: $10.1177 / 0002764209338800$

[10] Daniel A. Bell, "From Marx to Confucius: Changing Discourses on China's Political Future", Dissent, vol. 54, no. 2, 2007, pp. 20-28. DOI: $10.1353 / \mathrm{dss} .2007 .0061$

[11] Qing Jiang, The conception of Rebuilding Chinese Confucianism, Aisixiang, 2009. http://www.aisixiang.com/data/28639.html

[12] Ruiping Fan, Erika Yu, The Renaissance of Confucianism in Contemporary China, Springer, 2011, pp. 38.

[13] Xiaoguang Kang, Benevolent Governance-The Legitimacy Theory of Authoritarian States, China Digital Space, 2004.

[14] Yingshi Yu, Contemporary Significance of Chinese culture from the Perspective of Value System, Taiwan: China Times Publishing, 1992.

[15] D. Sturgeon, "The Analects: Xue Er", Chinese Text Project, 2016, DOI: ctext.org/analects/xue-er 